\title{
A method to estimate the damage of Diabrotica speciosa larvae on potato tubers
}

\author{
Marcos Roberto Barboza ${ }^{1 \mathbb{D}}$; Vitor Hugo Outeiro ${ }^{1 \mathbb{D}}$; Alessandra Tokarski ${ }^{1 \mathbb{D}}$; Caroline Rech ${ }^{1 \mathbb{D}}$; Jackson \\ Kawakami ${ }^{1 \mathbb{D}}$; Cristiane Nardi ${ }^{1 \mathbb{D}}$
}

${ }^{1}$ Universidade Estadual do Centro-Oeste, Departamento de Agronomia (UNICENTRO), Guarapuava-PR, Brasil; barbozabio@yahoo.com. br; vitorhugoouteiro@yahoo.com.br; alessandra_tokarski@hotmail.com; caroline_rech@outlook.com;jkawakami@unicentro.br; cnardi@ alumni.usp.br

\begin{abstract}
The marketable value of potato tubers is affected by damage caused by Diabrotica speciosa, whose larvae create holes on the tubers' skin and internal feeding tunnels. The estimation of potato tuber damage is usually performed by assessing the external damage to the detriment of feeding tunnels caused by larvae. Thus, we propose a method to estimate the damage caused by $D$. speciosa larvae, considering the external and internal aspects of the tubers separately. For that, potato plants cv. Agata were grown under different infestations of larvae, measuring the area occupied by the holes and the volume of internal feeding tunnels, relating these data to the total area and volume of the tuber. The methodology used allowed us to characterize an increase in damage in tubers with the highest infestation of larvae. The correlation between internal and external damage caused by $D$. speciosa larvae was not significant, indicating that external damage alone is not an adequate parameter for the diagnosis of overall tuber quality. However, the method proposed here provides information regarding the volume of pulp consumed by the larvae, the extent of the galleries formed, and the relative volume of damage concerning the total tuber. Moreover, the method proposed here contemplates a more precise analysis of the external area damaged by herbivory relative to the total area of the tuber, which is not commonly considered in studies of underground plant structures.
\end{abstract}

Keywords: Solanum tuberosum, cucurbit beetle, damage estimation, pest management, rootworm.

\begin{abstract}
RESUMO
Método para estimar o dano de larvas de Diabrotica speciosa em tubérculos de batata

O valor comercial dos tubérculos de batata é afetado pelos danos causados por Diabrotica speciosa, cujas larvas fazem orifícios na casca dos tubérculos e túneis internos. A estimativa dos danos aos tubérculos de batata é geralmente realizada avaliando os danos externos, em detrimento dos túneis de alimentação causados por larvas. Assim, propomos um método para estimar os danos de D. speciosa, considerando os aspectos externos e internos dos tubérculos separadamente. Para tanto, plantas de batata cv. Ágata foram cultivadas sob diferentes infestações de larvas, medindo-se a área ocupada pelos buracos e o volume dos túneis de alimentação internamente, relacionando esses dados com a área total e o volume do tubérculo. A metodologia utilizada permitiu caracterizar o aumento dos danos nos tubérculos com maior infestação de larvas. A correlação entre os danos internos e externos causados por larvas de $D$. speciosa não foi significativa, indicando que o dano externo por si só não é um parâmetro adequado para o diagnóstico da qualidade geral do tubérculo. No entanto, o método aqui proposto fornece informações sobre o volume de polpa consumido pelas larvas, a extensão das galerias formadas e o volume relativo de danos em relação ao tubérculo total. Além disso, o método aqui proposto contempla uma análise mais precisa da área externa danificada pela herbivoria em relação à área total do tubérculo, o que não é comumente considerado em estudos de estruturas de plantas subterrâneas.
\end{abstract}

Palavras-chave: Solanum tuberosum, estimativa de danos, manejo de pragas, larva-alfinete; vaquinha-verde-amarela.

\section{Received on March 16, 2021; accepted on July 5, 2021}

$\mathrm{P}_{\mathrm{o}}^{\mathrm{o}}$ tato (Solanum tuberosum) is one of the most consumed foods globally, with a global production of approximately 370 million tons per year (Fao, 2020). In Brazil, the crop cycle is around 100 days and, although it may vary according to regions, cultivars and climate, this is the period in which tubers remain exposed to rhizophagous insect damage, which reduces the quality and commercial value of the products (Brasil, 2017; Dray Junior \& Goldstein,
2020).

One of the main limiting factors to potato crop yield is insects' susceptibility, which results in high amounts of pesticide used throughout the crop cycle, increasing production costs and drastically affecting the environment and human health (Lara et al., 2004; Trecha et al., 2016). Diabrotica speciosa (Coleoptera, Chrysomelidae), popularly known as "vaquinha" or "brasileirinho", is one of the most important herbivorous insects of the potato crop in Brazil, occurring in all South American countries except Chile (Ávila \& Santana, 2016; Cabrera Walsh et al., 2020). The larvae of this insect are subterranean and hatch from eggs laid by females near the plants. In potato, the larvae perforate the tubers causing dark circular holes, besides making holes in the shape of galleries (tunnel-shaped), which can house excrement and favor the establishment 
of microorganisms inside the tuber (Lara et al., 2004).

The damage caused by $D$. speciosa in potato tubers is exceptionally detrimental to commercialization (Brasil, 2017). Despite the insects' importance as a pest in the crop, predefined scales to evaluate damage are not available, which generates inaccurate results and is often difficult to replicate. Most commonly, mechanical damage to potato tubers, including that caused by $D$. speciosa, is assessed from a visual estimate by the proportion occupied by the holes in relation to the surface part of the structure (Brasil, 2017). There are also studies in which the intensity of damage is estimated by counting the number of holes formed by the larvae in the tubers (Salles, 2000; Lara et al., 2004; Tobih et al., 2007) that disregards the size and proportion of the tuber targeted by the injury. Another possible method would be biomass assessment, estimating the loss after plant exposure to the insect (Okoroafor et al., 2014), which does not apply to $D$. speciosa herbivory in potato since biomass loss is minimal and hardly detectable.

Currently, the most suitable methods for assessing insect damage to underground plant structures are those that use volume and area as the basis for accurate and replicable calculations (Dray Junior \& Goldstein, 2020); Following what occurs with foliar pests, on roots and tubers, images can also be obtained to perform the estimates on flat, uniform plant structures. However, since the holes and galleries formed by $D$. speciosa larvae in potatoes occur at different sizes and depths in the tuber, the use of images would be hampered.

Within this context, we propose a method to estimate $D$. speciosa damage in potato tubers that considers the external and internal aspects separately, in order to provide subsidies for a more precise estimate of larval damage.

\section{MATERIAL AND METHODS}

Adults of D. speciosa were fed on bean (Phaseolus vulgaris) leaves and kept in plastic cages, which contained oviposition substrate (Ávila et al.,
2000). The obtained eggs were kept in Petri dishes with moistened filter paper until the larvae hatched. Newly hatched larvae were inoculated in plastic containers $(300 \mathrm{~mL})$ and fed on radicles of popcorn seedlings (Zea mays var. Everta) with expanded vermiculite as substrate. For the experiments, larvae 8-10 days old after hatching were used. During the entire rearing process, the insects were kept in a climate-controlled room at $25 \pm 2{ }^{\circ} \mathrm{C}$ temperature and $12 \mathrm{~h}$ photophase.

Potato tuber (Solanum tuberosum cv. Agata) was planted in pots $(20 \mathrm{~L})$ filled with soil added with $38 \mathrm{~g}$ of NPK fertilizer (4-14-8). The plants were kept in the greenhouse during the entire cycle and subjected to daily irrigation and disease control as recommended for the crop. Second and third instar larvae (8-10 days old) of D. speciosa were inoculated in the soil near the roots of the plants at 15, 30, 45 and 60 days after plant emergence to induce damage. The treatments consisted of different numbers of larvae per inoculation $(0,20,40$ and 80 larvae), with four replicates per treatment in a completely randomized design.

Five tubers were randomly obtained from each plant, totaling 20 per treatment, to quantify the damage caused by larvae. The tubers were washed in tap water, measured in length and diameter and evaluated for external and internal damage. For external damage evaluation, the holes caused by $D$. speciosa were measured and quantified. All circular holes containing a dark spot in the center were considered characteristic of $D$. speciosa injury (Figure 1A). For internal damage evaluation, the tubers were sectioned in $0.5-1.0 \mathrm{~cm}$ slices to assess the number, length and diameter of galleries formed due to larval feeding (Figure 1B). The galleries formed by $D$. speciosa were considered to be tunnel-shaped openings with necrotic sides (Figure 1C). Each gallery was measured with a caliper in its length and width (Figure 1D), and the proportion of the total volume of the galleries in relation to the total volume of each tuber was calculated.

Although there are cultivars with spherical-shaped tubers, most cultivars used for fresh consumption have elliptically shaped tubers. Thus, to calculate the volume and area, each tuber was considered an ellipsoid of revolution obtained by rotating an ellipse, with a center at $(0,0)$, around the $x$-axis. For the calculation, the major axis of the ellipse was always considered to be on the x-axis. Thus, the volume of each tuber was given by equation 1 and the area by equation 2 . The volume of the galleries, considered as cylinders, formed in each tuber is given by equation 3 .

Equation 1

$$
V t=\int_{-a}^{a} \pi[f(x)]^{2} d x=\frac{4}{3} \pi a b^{2}
$$

Equation 2

$$
\begin{aligned}
& A t=2 \pi \int_{-a}^{a} f(x) \sqrt{1+f^{\prime}(x)^{2}} d x \\
& =\frac{2 \pi b}{a^{2}}\left[\frac{\sqrt{\left(b^{2}-a^{2}\right) x}}{2} \sqrt{\left(a^{4}+\left(b^{2}-a^{2}\right) x^{2}\right)}\right. \\
& +\frac{a^{4}}{2} \ln \left(\left(\sqrt{\left(b^{2}-a^{2}\right)}\right) x\right. \\
& \left.\left.+\sqrt{\left(a^{4}+\left(b^{2}-a^{2}\right) x^{2}\right)}\right)\right]_{-a}^{a}
\end{aligned}
$$

Where:

$$
y=f(x)=\frac{b}{a} \sqrt{a^{2}-x^{2}}
$$

was isolated from ellipse

$$
\frac{x^{2}}{a^{2}}+\frac{y^{2}}{b^{2}}=1
$$

$a$ is the minor axis of the ellipse, and $b$ is the major axis.

Equation 3

$$
V g=\sum_{i=1}^{n} \pi r^{2} h_{i}
$$

Where: $r$ is the radius of the gallery (the average radius of $0.1 \mathrm{~cm}$ was used to calculate the volume of all tunnels) and $h_{i}$ is the length of gallery $\mathrm{i}$. $\mathrm{i}=1,2,3, \mathrm{n}$, where $\mathrm{n}$ is the umpteenth gallery.

After calculating the area and volume of tubers and galleries, the percentages of internal and external damage were calculated for each tuber. The percent internal damage (ID) was calculated by equation 4 , and the percent external damage (ED) was calculated by equation 5 .

Equation 4

$$
I D(\%)=\frac{V g}{V t} 100
$$


Equation 5

$$
E D(\%)=\frac{n \pi r^{2}}{A t} 100
$$

Where: $\mathrm{Vg}$ is the volume of the galleries in each tuber, $\mathrm{Vt}$ is the volume of the tuber, $n$ is the number of tunnels in the evaluated tuber, $\mathrm{r}=0.1 \mathrm{~cm}$ and $A t$ the area of the ellipsoid.

Data regarding internal and external damage were subjected to ANOVAKruskal-Wallis Median Test and to multiple comparisons by KruskalWallis test $(\mathrm{p}<0.05)$. For comparisons between tubers separated by size, data were subjected to comparisons between two independent samples by the Mann-Whitney test $(\mathrm{p}<0.05)$. The number of holes and galleries and the percentage of ED and ID verified at different infestations were subjected to regression analysis $\left(\mathrm{p}<0.05 ; \mathrm{R}^{2} \geq 0.80\right)$. Spearman's correlation test was used for the ID and ED in each treatment and to analyze the correlation of each of the variables analyzed. The analyses were performed using Statistica 7.0 software (StatSoft Inc, 2004).

\section{RESULTS AND DISCUSSION}

Internal (ID) and external damage (ED) of D. speciosa was evident at all levels of infestation. The greater the number of inoculated larvae, the higher the level of tuber's damage, with a significant correlation between infestation level and ED (Figure 2A, 2B) $\left(\mathrm{R}^{2}=0.9839\right)$, and between infestation level and internal damage (Figure 2C, 2D) $\left(R^{2}=0.9724\right)$.

In the skin of the evaluated tubers, we recorded an average of 12 holes per tuber with an area of $0.015 \mathrm{~cm}^{2}$ per hole, which caused average ED of $0.42 \%$ (Table 1). The average number of holes per tuber was proportional to the percentage of ED calculated but with a positive correlation of less than $90 \%$ (Spearman, $\mathrm{p}<0.05, \mathrm{R}^{2}=0.79$ ). However, when separating tubers by size (diameter $\geq 3.3 \mathrm{~cm}$ and diameter $<3.3 \mathrm{~cm}$ ), the same number of holes caused a higher damage percentage in tubers with smaller surface area (Mann Whitney U-test, $\mathrm{p}=0.014$ ) (Table 2).

Inside the tubers, the number of galleries formed in the pulp varied from 1 to 50, with an average of 11.96 (Table 1). There was a positive and significant correlation between the number of internal galleries and the number of external holes (Spearman, $\mathrm{p}<0.05, \mathrm{R}^{2}=$ $0.99)$. However, the number of external holes was not related to the percentage of ID (Spearman, $\mathrm{p}<0.05, \mathrm{R}^{2}=0.33$ ) or the volume of galleries (Spearman, $\left.\mathrm{p}<0.05, \mathrm{R}^{2}=0.46\right)$ with correlation values less than $50 \%$ (Table 3 ).

Although there is a positive correlation between the number of holes
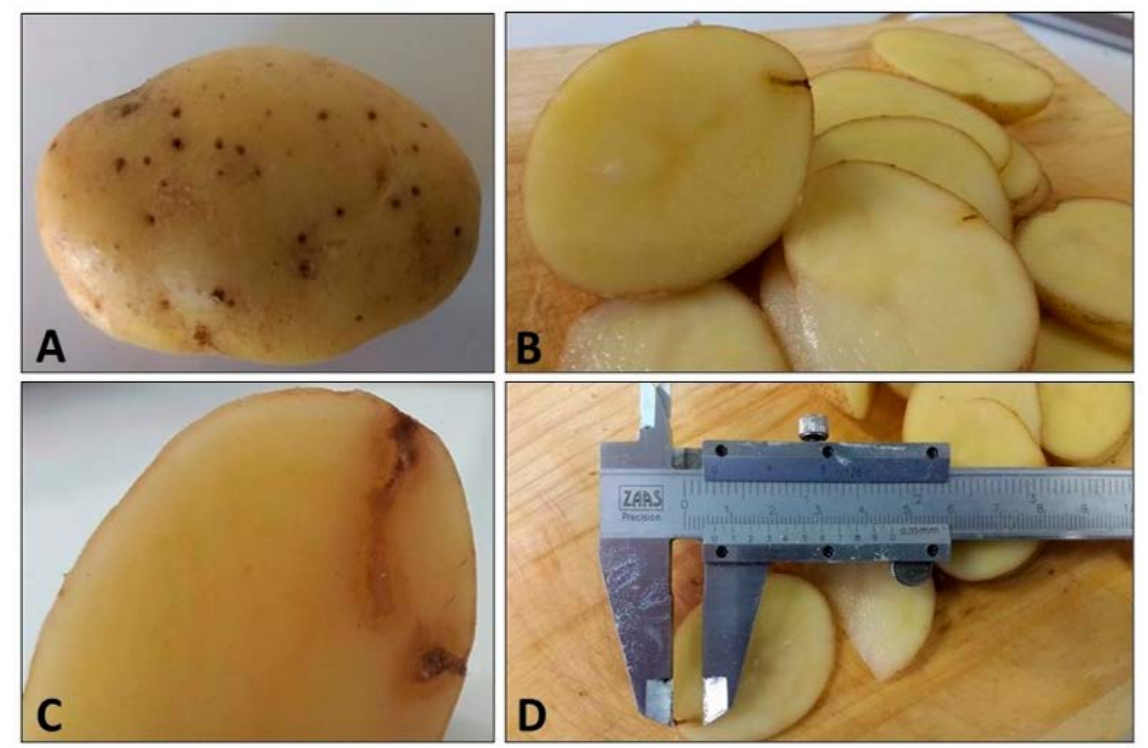

C

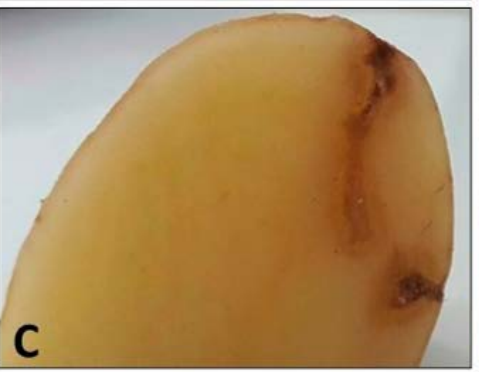

and the percentage of ED, estimating damage by the number of holes alone is flawed because it does not consider tuber size. In this study, by separating small $(<3.3 \mathrm{~cm})$ and large $(\geq 3.3 \mathrm{~cm})$ tubers with the same number of holes, it was shown that the level of ED varies as a function of tuber surface area. In general, a quantitative study of the attacked area to highlight resistance levels of cultivars is abundant and used for numerous plant species, especially when it comes to leaves or above ground plant structures (Imura \&

Figure 1. Potato tubers (Solanum tuberosum cv. Ágata) damaged by Diabrotica speciosa larvae: A. External holes made by the larval feeding; B. Internal feeding tunnels; C. Detail showing the feeding tunnels; D. Measuring procedure to estimate the internal damage with a caliper. Guarapuava, Unicentro, 2019.

Table 1. Data used to estimate the external (ED) and internal damage (ID) of Diabrotica speciosa larvae in potato tubers (Solanum tuberosum cv. Ágata). Guarapuava, Unicentro, 2019.

\begin{tabular}{lrccc}
\hline External damage & Mean & Minimum & Maximum & $\begin{array}{c}\text { Standard } \\
\text { deviation }\end{array}$ \\
\hline Number of holes & 12.0 & 1 & 54 & 11.7 \\
Area of one hole $\left(\mathrm{cm}^{2}\right)$ & 0.015 & 0.002 & 0.088 & 0.014 \\
Area of all holes $\left(\mathrm{cm}^{2}\right)$ & 0.210 & 0.002 & 1.418 & 0.279 \\
Surface area of tubers $\left(\mathrm{cm}^{2}\right)$ & 73.930 & 13.290 & 206.180 & 36.290 \\
ED (\%) & 0.420 & 0.002 & 6.660 & 0.900 \\
\hline Internal damage & & & & \\
\hline Number of tunnels & 11.96 & 1 & 50 & 10.91 \\
Diameter of tunnels & 0.126 & 0.050 & 0.335 & 0.050 \\
Volume of the tunnels $\left(\mathrm{cm}^{3}\right)$ & 0.011 & 0.004 & 0.375 & 0.040 \\
Total volume of tubers $\left(\mathrm{cm}^{3}\right)$ & 80.520 & 5.900 & 232.720 & 54.520 \\
ID $(\%)$ & 0.032 & 0.001 & 1.477 & 0.160 \\
\hline
\end{tabular}


Ninomiya, 1998; Teodoro et al., 2014; Cutti et al., 2019). However, when it comes to spherical or ellipsoid-shaped structures such as the potato tuber, the method needs adjustments to estimate the total area and the area damaged by herbivores. In this sense, the calculation of the area considering the rotation of the ellipsoid in potatoes favors greater

accuracy in measuring the ED caused by $D$. speciosa larvae.

The methodology proposed here hypothesized that the number of holes is not representative of the percentage of ID since not all holes give rise to galleries. Furthermore, the galleries formed after the hole drilling may have different extensions and diameters.

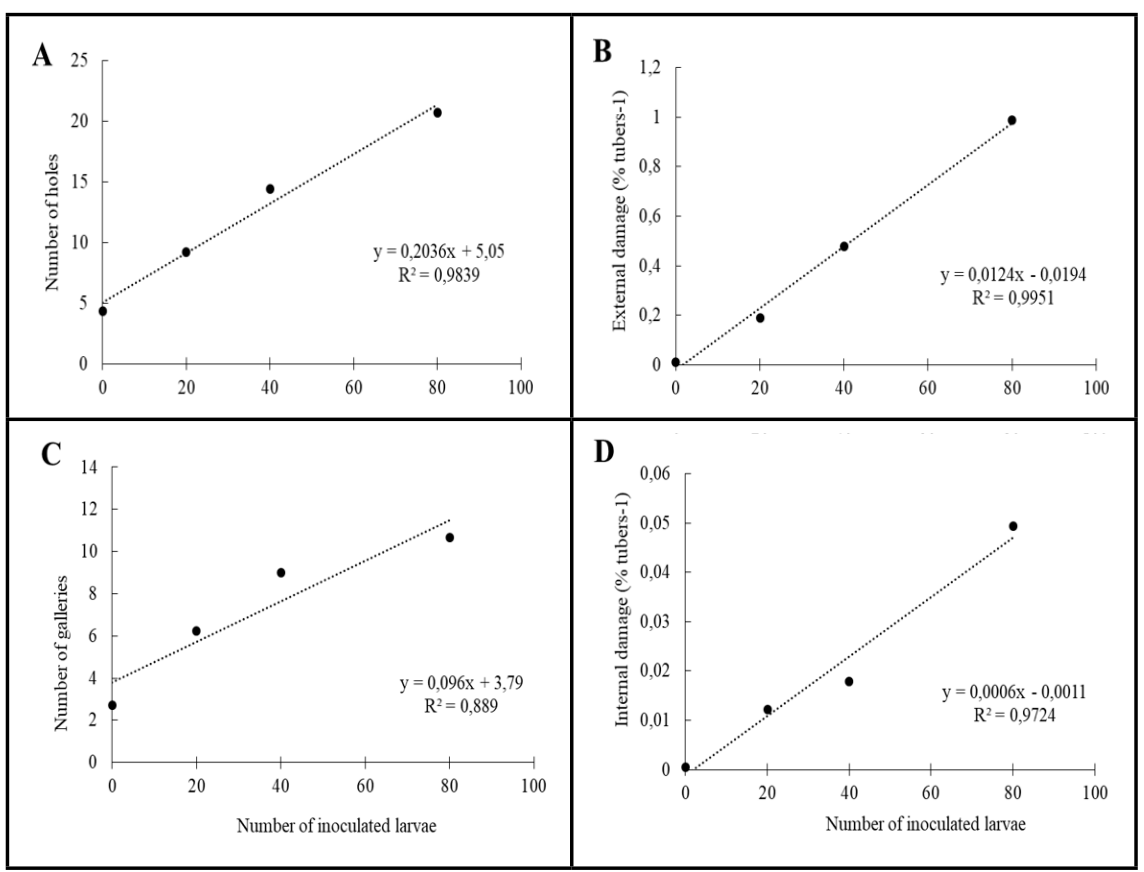

Figure 2. External (A, B) and internal (C, D) damage in potato tubers (Solanum tuberosum cv. Ágata) due to different infestations of Diabrotica speciosa larvae in a greenhouse bioassay. Guarapuava, Unicentro, 2019.

Table 2. The average area of small (diameter $<3.3 \mathrm{~cm}$ ) and big (diameter $\geq 3.3 \mathrm{~cm}$ ) potato tubers and the external damage (ED) caused to these tubers (Solanum tuberosum cv. Ágata) by larvae of Diabrotica speciosa under artificial infestation in a greenhouse $(\mathrm{N}=11)$. Guarapuava, Unicentro, 2019.

\begin{tabular}{lcc}
\hline \multirow{2}{*}{ Analyzed variables } & \multicolumn{2}{c}{ Size of tubers } \\
\cline { 2 - 3 } & $\begin{array}{c}\text { Small } \\
\text { (diameter }<\mathbf{3 . 3} \mathbf{~ c m})\end{array}$ & $\begin{array}{c}\text { Large } \\
\text { (diameter } \geq \mathbf{3 . 3} \mathbf{~ c m} \text { ) }\end{array}$ \\
\hline Average area of tubers $\left(\mathrm{cm}^{2}\right)$ & $22.4 \pm 7.5$ & $63.7 \pm 23.5$ \\
Number of holes & 20 & 20 \\
Area of all holes $\left(\mathrm{cm}^{2}\right)$ & $0.35 \pm 0.53 \mathrm{a}$ & $0.32 \pm 0.12 \mathrm{a}$ \\
ED $(\%)$ & $1.59 \pm 1.6 \mathrm{a}$ & $0.62 \pm 0.44 \mathrm{~b}$ \\
\hline
\end{tabular}

Table 3. R values estimated by Spearman's linear correlation $(p<0.05)$ between the number of external holes and the external (ED) and internal damage (ID) caused by Diabrotica speciosa larvae in potato tubers (Solanum tuberosum cv. Ágata). Guarapuava, Unicentro, 2019.

\begin{tabular}{lc}
\hline Analyzed variables & Number of holes \\
\hline ED (\%) & 0.796 \\
Number of tunnels & 0.991 \\
Volume of tunnels & 0.461 \\
ID $(\%)$ & 0.332 \\
\hline
\end{tabular}

Our work found that although there is a positive correlation between the number of galleries and external holes, the correlation is not significant between ID and ED caused by D. speciosa larvae. This result shows that ED alone is often not an adequate parameter for diagnosing overall tuber quality, mainly when different cultivars or plant resistance mechanisms are evaluated. Thus, evaluating resistant cultivars, for example, one should consider that although external holes may appear, characteristics of the flesh may imply that the insect did not feed.

Furthermore, in studies on plant resistance mechanisms to insects, it is essential to characterize the effective consumption of the herbivore in order to estimate the intensity of damage caused, as well as the effect of feeding on the biology and behavior of the insect (Baisden et al., 2018). In this sense, by estimating only the ED, one would not have a satisfactory conclusion about the effective resistance of a cultivar. The consumption of $D$. speciosa larvae in potato tubers is more precisely measured by evaluating ID. So, volumetric characterization of ID can provide subsidies to breeding programs for genetic improvement of cultivars' resistance to herbivorous insects and help validate or characterize the results of possible resistance mechanisms existing in the plant (Dray Junior \& Goldstein, 2020).

Methodologies for evaluating damage to underground plant parts are less frequent than those available for measuring damage to aboveground organs. This difference reveals the importance and the need for studies to develop methods for this, aiming to expand accuracy and standardization in measuring damage to roots, tubers, and other underground plant structures (Souza et al., 2008; Dray Junior \& Goldstein, 2020; Rondon, 2020). For $D$. speciosa, whose larvae can damage several commercial crops, the bestestablished methodology is adopted in maize, based on an adaptation to assess the extent of galleries in roots caused by $D$. virgifera virgifera (Oleson et al., 2005; Dun et al., 2010). However, for potato tubers and tuberous roots 
of sweet potato (Ipomea batatas), for example, damage characterization has been carried out based on the number of holes caused by the insects, without considering the relative area they occupy, nor the extent of galleries formed internally by the larvae (Salles, 2000; Blank et al., 2001; França \& Ritschel, 2002; Tobih et al., 2007).

For other subterranean insects, methodologies have recently been proposed to achieve greater accuracy in estimating damage, similar to what occurs for insects of aerial plant parts. Volumetric analysis to estimate ID is pointed out as one of the most feasible methods, as it accurately considers the volume consumed by the insect relative to the total volume of the structure (Dray Junior \& Goldstein, 2020). These methods can vary in how to access the volumetric data, which can be based on diameter measurements as proposed in the present study or by adding liquids into the holes generated by the insects. Dray Junior \& Goldstein (2020) injected water and resin into the galleries formed by Lilioceris cheni and L. egena (Coleoptera: Chrysomelidae), and the amounts of liquids injected indicated the extent of damage from feeding by the insects. Thus, the authors demonstrated the advantages of volumetric analysis over other methods of estimating tuber damage.

However, the methodology proposed here provides information on the volume of pulp consumed by the larvae and the extent of the galleries formed and the relative volume of damage in relation to the total tuber. Moreover, the method proposed here provides a more precise analysis of the external area damaged by herbivores relative to the total area of the tuber, which is not commonly considered in studies of underground plant structures.

\section{ACKNOWLEDGMENTS}

The authors thank the anonymous reviewers for their helpful comments.
This research was supported by the National Institute of Science and Technology, Semiochemicals in Agriculture (FAPESP and CNPq, grants \#2014/50871-0 and \#465511/2014-7, respectively).

\section{REFERENCES}

ÁVILA, CJ; SANTANA, AG. 2016. Danos causados as culturas por adultos e larvas de Diabrotica speciosa, In: NAVA, DE; ÁVILA, CJ; PINTO, AS (eds). Diabrotica speciosa. Piracicaba, BR: Occasio. 59-67 pp.

ÁVILA, CJ; TABAI, ACP; PARRA, JRP. 2000 Comparação de técnicas para criação de Diabrotica speciosa (Germar) (Coleoptera: Chrysomelidae) em dietas natural e artificial. Anais da Sociedade Entomológica do Brasil 29: 257-267.

BAISDEN, EC; TALLAMY, DW; NARANGO, DL; BOYLE, E. 2018. Do cultivars of native plants support insect herbivores? HortTechnology 28: 596-606.

BLANK, AF; SILVA, PA.; TORRES, MER; ARRIGONI-BLANK, MF. 2001. Avaliação de genótipos de batata-doce quanto à resistência aos insetos de solo no Estado de Sergipe. Ensaios e Ciências: Ciências Biológicas, Agrárias e da Saúde 5: 27-34.

BRASIL. 2017. Instrução normativa $\mathrm{n}^{\circ} 27$, de 17 de julho de 2017. Estabelece o regulamento técnico da batata, definindo o seu padrão oficial de classificação, com os requisitos de identidade e qualidade, a amostragem, o modo de apresentação e a marcação ou rotulagem, nos aspectos referentes à classificação do produto. Diário oficial da união. Ministério de estado da agricultura, pecuária e abastecimento, Brasília, DF, July 18, 2017. Seção 1, p.8.

CABRERA WALSH, G; ÁVILA, CJ, CABRERA N, NAVA, D; PINTO, AS; WEBER, DC. 2020. Biology and management of pest Diabrotica species in South America. Insects 11: 421.

CUTTI, L; MURARO, DS; SILVA, VA; KASPARY, TE; BASSO, CJ; ROGGIA, S. 2019. Leaf consumption and preference to Conyza sp., conventional and Bt soybean by Helicoverpa armigera. Planta Daninha 37: e019211566.

DRAY JUNIOR, FA; GOLDSTEIN, SL. 2020. A novel method for quantifying insect damage to plant storage organs. Entomologia Experimentalis et Applicata 168: 113-117.

DUN, Z; MITCHELL, PD; AGOSTI, M. 2010. Estimating Diabrotica virgifera virgifera damage functions with field trial data: applying an unbalanced nested error component model. Journal of Applied Entomology 134: 409-419.

FAO, Food and Agriculture Organization of the United Nations. 2020. Rome. Available at $<$ http://www.fao.org/faostat/en/\#home $>$. Accessed March 03, 2021.

FRANÇA, FH; RITSCHEL PS. 2002. Avaliação de acessos de batata-doce para resistência à broca-da-raiz, crisomelídeos e elaterídeos. Horticultura Brasileira 20: 79-85.

IMURA, O; NINOMIYA, S. 1998. Quantitative measurement of leaf area consumption by Epilachna vigintioctopunctata (Fabricius) (Coleoptera: Coccinellidae) using image processing. Applied Entomology and Zoology 33: 491-495.

LARA, FM; SCARANELLO, AL; BALDIN, ELL; BOIÇA JÚNIOR, AL; LOURENÇÃO, AL. 2004. Resistência de genótipos de batata a larvas e adultos de Diabrotica speciosa. Horticultura Brasileira 22: 761-765.

OKOROAFOR, E; ONU, I; AMATOBI, CI. 2014. Laboratory evaluation of botanical effect on yam tuber beetle (Heteroligus meles Bill-berger) (Coleoptera: Dynastidae) damage and weight loss in white yam (Dioscorea rotundata Poir). IOSR Journal of Agriculture and Veterinary Science 7: 12-15.

OLESON, JD; PARK, Y; NOWATZKI, TM; TOLLEFSON, JJ. 2005. Node-injury scale to evaluate root injury by corn rootworms (Coleoptera: Chrysomelidae). Journal of Economic Entomology 98: 1-8.

RONDON, SI. 2020. Decoding Phthorimaea operculella (Lepidoptera: Gelechiidae) in the new age of change. Journal of Integrative Agriculture 19: 316-324.

SALLES, LA. 2000. Incidência de danos de Diabrotica speciosa em cultivares e linhagens de batata. Ciência Rural 30: 2055-209.

SOUZA, VQM; PEREIRA, AS; SILVA, GO; FRITSCHE NETO, R; CASTRO, CM. 2008. Avaliação de genótipos de batata selecionados para resistência a insetos-praga. Available at $<$ https://ainfo.cnptia.embrapa.br/digital/ bitstream/item/30403/1/boletim-65.pdf $>$. Accessed March 02, 2021.

STATSOFT, INC. 2004. STATISTICA (data analysis software system), version 7. Available at $<$ www.statsoft.com $>$. Accessed March 3, 2021.

TEODORO, JS; MARTINS, JFS; ROSA, APSA; CASTRO, CM; CUNHA, US. 2014. Characterization of potato genotypes for resistance to Diabrotica speciosa. Horticultura Brasileira 32: 440-445.

TOBIH, FO; EMOSAIRUE, SO; OKONMAH, LU. 2007. Studies on the occurence and damage by yam tuber beetles (Heteroligus spp.) in Aniocha and Oshimili areas of Delta State, Nigeria. Journal of Central European Agriculture 8: 129-134.

TRECHA, CO; HELLWING, L; ROSA, APSA; BARROS, WS; MAUCH, CR. 2016. Efeito da infestação de larvas de Diabrotica speciosa em tubérculos de batata em períodos de calor e frio. Available at $<$ https://ainfo.cnptia. embrapa.br/digital/bitstream/item/145138/1/ Circular-171.pdf $>$. Accessed March 02, 202 